\title{
Prevalence of soft tissue calcifications in cone beam computed tomography images of the mandible
}

\author{
Prevalência de calcificações em tecido mole na região mandibular \\ avaliadas por dois sistemas de tomografia computadorizada \\ por feixe cônico
}

\begin{abstract}
Purpose: To determine the prevalence of soft tissue calcifications in the mandible in cone beam computed tomography (CBCT) scans.

Methods: The sample was composed by 246 CBCT scans of the mandible; 163 were acquired by the NewTom $3 \mathrm{G}^{\circledR}$ system, and 83 were acquired by the Classic i-Cat ${ }^{\circledR}$ system. When the presence of soft tissue calcification was confirmed in the mandible, the anatomical location and the type of calcification (single or multiple) were determined. Elongated styloid process and ossification of the stylohyoid ligament were excluded. Data were analyzed by using Fisher's exact test and chi-square tests.

Results: A total of 37 out of 246 scans showed soft tissue calcifications in the mandible (prevalence of $15 \%$ ). Soft tissue calcification is predominant at posterior region of the mandible (18.9\%), with no relation to gender and age. From the total of patients with soft tissue calcification, 73\% were aged 35-55 year-old. There was no significant difference of diagnostic quality of the images between the CBCT systems $(P>0.05)$.

Conclusion: The prevalence of soft tissue calcifications was high in this sample using CBCT images for diagnosis in the mandibular region.
\end{abstract}

Key words: Cone beam computed tomography; hyperdense images; soft tissue calcification

\section{Resumo}

Objetivo: Determinar a prevalência de calcificações em tecido mole na região mandibular por meio de análise de imagens axiais provenientes de dois sistemas de tomografia computadorizada por feixe cônico (TCFC), NewTom $3 \mathrm{G}^{\circledR}$ e Classic i-Cat ${ }^{\circledR}$.

Método: Foram avaliadas 246 imagens da região mandibular. Destas, 163 foram adquiridas no aparelho NewTom $3 \mathrm{G}^{\circledR}$ e 83 no aparelho Classic i-Cat ${ }^{\circledR}$. A análise estatística foi baseada no teste exato de Fisher e no teste Qui-quadrado para comparação das proporções.

Resultados: Das 246 imagens, 37 apresentaram calcificações em tecido mole. Não houve diferença significativa entre gêneros em termos de prevalência. Pacientes entre 40-65 anos foram os mais afetados. A prevalência de calcificações em tecido mole na região mandibular foi de $15 \%$, não havendo diferença significante entre os dois sistemas de TCFC quanto à qualidade das imagens para o diagnóstico $(P>0,05)$.

Conclusão: Os sistemas de TCFC avaliados mostraram-se ferramentas valiosas na identificação de calcificações em tecido mole, embora as imagens não permitam exata localização destas calcificações.

Palavras chave: Calcificação em tecido mole; tomografia computadorizada por feixe cônico; imagens hiperdensas; mandíbula

\author{
Leiliane Ferreira da Silva Nunes ${ }^{a}$ \\ Karina Cecília Panelli Santos ${ }^{b}$ \\ José Luiz Cintra Junqueira ${ }^{a}$ \\ Jefferson Xavier Oliveira ${ }^{b}$ \\ - Faculty of Dentistry São Leopoldo Mandic, \\ Campinas, SP, Brazil \\ b Faculty of Dentistry, University of São Paulo (USP), \\ São Paulo, SP, Brazil
}

\author{
Correspondence: \\ Karina Cecília Panelli Santos \\ Faculdade de Odontologia da USP \\ Disciplina de Radiologia \\ Av. Prof. Lineu Prestes, 2227, Cidade Universitária \\ São Paulo, SP - Brasil \\ 05508-000 \\ E-mail:kapanelli@hotmail.com
}

Received: June 1, 2011

Accepted: November 15, 2011

Conflict of Interests: The authors state that there are no financial and personal conflicts of interest that could have inappropriately influenced their work.

Copyright: (C) 2011 Nunes et al.; licensee EDIPUCRS This is an Open Access article distributed under the terms of the Creative Commons AttributionNoncommercial-No Derivative Works 3.0 Unported License. 


\section{Introduction}

Soft tissue calcifications are classified as dystrophic, idiopathic, or metastatic. They might not be accompanied by clinical symptoms or appear on X-rays $(1,2)$. One of the greatest difficulties when diagnosing soft tissue calcifications is to determine their exact location. This is especially difficult in panoramic radiographs, since two-dimensional images can create ghost images (3). However, since the last decade, volumetric imaging has been increasingly used as a diagnostic tool. The cone beam computed tomography (CBCT), an imaging method that allows the acquisition of high-quality, high-fidelity images using lower doses of radiation, facilitates the acquisition of multiplanar images and may allow a more accurate diagnosis for an effective treatment planning (4).

According to the guidelines of the American Academy of Oral and Maxillofacial Radiology, CBCT images constitute a valuable tool for determining the location of soft tissue calcifications by oral and maxillofacial radiology specialists (5).

The objective of the present study was to determine the prevalence of soft tissue calcifications in the mandibular region by analyzing $\mathrm{CBCT}$ axial images acquired by two different CBCT scanners.

\section{Methods}

The study protocol was approved by the Institutional Ethics Committee.

The sample comprised CBCT scans acquired by two different systems: NewTom $3 \mathrm{G}^{\circledR}$ (Quantitative Radiology, Verona, Italy) and Classic i-Cat ${ }^{\circledR}$ (Imaging Sciences International, Hatfield, PA, USA). The NewTom $3 \mathrm{G}^{\circledR}$ system specifications were as follows: scan time of $36 \mathrm{~s}$, field of view of 9 inches, $120 \mathrm{kVp}$ and $22.85 \mathrm{mAs}$. The Classic $\mathrm{i}-\mathrm{Cat}{ }^{\circledR}$ system specifications were: scan time of $40 \mathrm{~s}$; field of view of $6 \mathrm{~cm} ; 120 \mathrm{kVp}$; and $5 \mathrm{~mA}$. Axial slices of $0.4 \mathrm{~mm}$ in thickness were obtained with the two systems.

The 163 images acquired by the NewTom $3 \mathrm{G}^{\circledR}$ system and the 83 images acquired by the Classic i-Cat ${ }^{\mathbb{R}}$ system were evaluated on an independent workstation. The axial slices obtained by the NewTom $3 \mathrm{G}^{\circledR}$ system were reconstructed by an in-built program, and the axial slices obtained by the Classic i-Cat ${ }^{\circledR}$ system were reconstructed by the program i-Cat Vision ${ }^{\circledR}$ (Imaging Sciences International). The reconstructed images were analyzed by two previously trained observers, which were dental radiologists with a minimum of five years of experience in CBCT.

In order to acquire the NewTom $3 \mathrm{G}^{\circledR}$ scans, the patients were positioned with the Frankfort plane perpendicular to the ground. A wax roll was placed in the anterior region in order to maintain the maxilla and the mandible apart, thus avoiding artifacts caused by the former. The area to be reconstructed in the mandibular region was selected, the axial slices being parallel to the base of the mandible. The "study" format, which allows the evaluation of serial slices, as well as of new slices in other planes, was selected. The "wind 3" option, which is more suitable for the observation of calcified structures, was also selected.

The Classic i-Cat ${ }^{\mathbb{B}}$ scans were acquired with the patient sitting upright, with the chin resting on the device, and the scanner light markers serving as a guide for the sagittal and Frankfort planes. The mandible protocol was selected for the scans.

CBCT examinations scanned the entire mandible. The calcifications analyzed in the present study were in the anatomical region of the mandible. Elongated styloid process and ossification of the stylohyoid ligament were excluded.

The data were collected according to the CBCT system: treatment protocol, gender, age, clinical indication for the exam, and presence/absence of calcification. When a calcification was suspected, coronal slices were examined to rule out ossification of the stylohyoid ligament. When the presence of soft tissue calcification was confirmed, the anatomical location (divided by region) and the type of calcification (single or multiple) were determined.

The following anatomical regions (Fig. 1) were assessed:

- regions A and F, which comprised the vestibular aspect of the mandible, extending from the lower first premolars to the edge of the scan (distally);

- regions $\mathrm{B}$ and $\mathrm{E}$, which comprised the lingual aspect of the mandible, extending from the lower first premolars to the edge of the scan (distally);

- region $\mathrm{C}$, which comprised the lingual aspect of the anterior teeth, from canine to canine; and

- region $\mathrm{D}$, which comprised the vestibular aspect of the anterior teeth, from canine to canine.

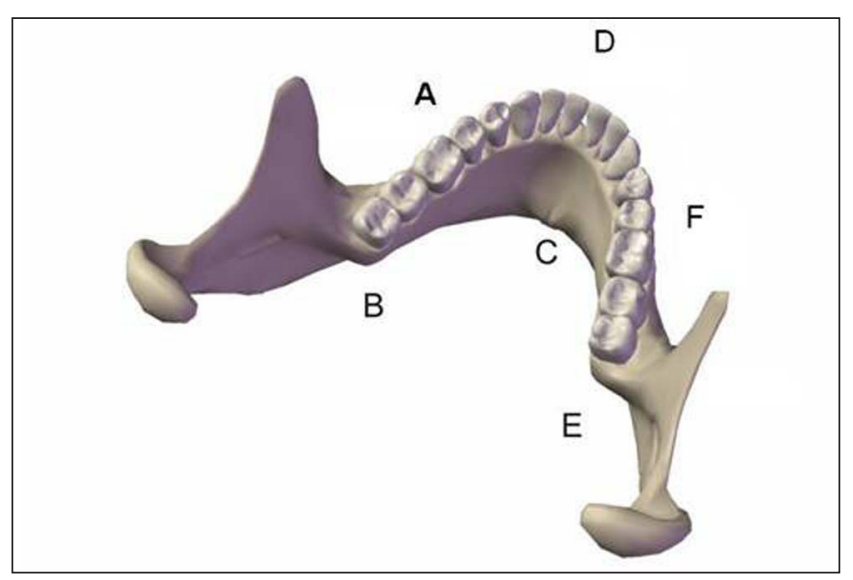

Fig. 1. Schematic illustration of the location of the calcifications in the axial plane.

The CBCT images were obtained independently for each case to compare the two CBCT systems for calcification detection. Gender and age groups were analyzed to verify a possible effect on the presence of soft tissue calcifications in the mandibular region. 
Data were statistically analyzed by using chi-square test for comparison of proportions (homogeneity) and Fisher's exact test. The Monte Carlo test was used in cases in which over $20 \%$ of the total of table cells had values lower than 5. For all statistical tests, the level of significance was set at $5 \%$.

\section{Results}

Although there was a significant difference between the number of NewTom $3 \mathrm{G}^{\circledR}$ scans and that of Classic i-Cat ${ }^{\circledR}$ scans, there were no significant differences between the two CBCT systems in terms of the proportions of individuals with and without soft tissue calcification $(P=0.85$; Table 1).

In order to evaluate the quantitative variable "age", patients were divided into age groups. The mean age of patients with soft tissue calcification was $44.98 \pm 11.24$ years. The youngest of the patients with calcification was aged
14 year-old, and the oldest was aged 65 year-old. From the total of patients with soft tissue calcification, $73 \%$ were aged 35-55 year-old (Table 2).

Figure 2 shows that soft tissue calcification was more frequent in regions B and E, 19\% of all calcifications were observed in these two regions simultaneously. The regions $\mathrm{B}$ and $\mathrm{E}$ were the only two mandibular regions that were simultaneously affected. Regions D and F were the least frequently affected. No soft tissue calcification was observed in region A (Fig. 2 and 3).

Figure 3 shows no significant differences between the two CBCT systems regarding the proportions of soft tissue calcifications detected (chi-square test with Monte Carlo simulation, $P=0.287$ ).

There were no significant differences between the different age groups in terms of the proportions of patients with single or multiple calcifications (chi-square test with Monte Carlo simulation, $P=0.056$ ) (Fig. 4).
Table 1. Relative and absolute frequencies of the presence or absence of soft tissue calcification, as determined by the two observers after the analysis of the images acquired by the two cone beam computed tomography systems evaluated.

Table 2. Relative and absolute frequencies of age groups in which soft tissue calcifications were present or absent

\begin{tabular}{lrrrrrr}
\hline \multirow{2}{*}{ CBCT system } & \multicolumn{6}{c}{ Calcification } \\
\cline { 2 - 7 } & \multicolumn{2}{c}{ No } & \multicolumn{2}{c}{ Yes } & \multicolumn{2}{c}{ Total } \\
\hline NewTom $^{\circledR}$ & 139 & $85.3 \%$ & 24 & $14.7 \%$ & 163 & $100.0 \%$ \\
i-Cat $^{\circledR}$ & 70 & $84.3 \%$ & 13 & $15.7 \%$ & 83 & $100.0 \%$ \\
Total & 209 & $85.0 \%$ & 37 & $15.0 \%$ & 246 & $100.0 \%$ \\
\hline
\end{tabular}

CBCT: cone beam computed tomography

\begin{tabular}{lrrrrrr}
\hline \multirow{2}{*}{ Age groups } & \multicolumn{5}{c}{ Calcification } \\
\cline { 2 - 8 } & \multicolumn{2}{c}{ No } & \multicolumn{3}{c}{ Yes } & \multicolumn{2}{c}{ Total } \\
\hline 35 years & 53 & $89.8 \%$ & 6 & $10.2 \%$ & 59 & $100.0 \%$ \\
$35-45$ years & 43 & $81.1 \%$ & 10 & $18.9 \%$ & 53 & $100.0 \%$ \\
$45-55$ years & 55 & $77.5 \%$ & 16 & $22.5 \%$ & 71 & $100.0 \%$ \\
$55-65$ years & 34 & $89.5 \%$ & 4 & $10.5 \%$ & 38 & $100.0 \%$ \\
$\geq 65$ years & 24 & $96.0 \%$ & 1 & $4.0 \%$ & 25 & $100.0 \%$ \\
Total & 209 & $85.0 \%$ & 37 & $15.0 \%$ & 246 & $100.0 \%$ \\
\hline
\end{tabular}

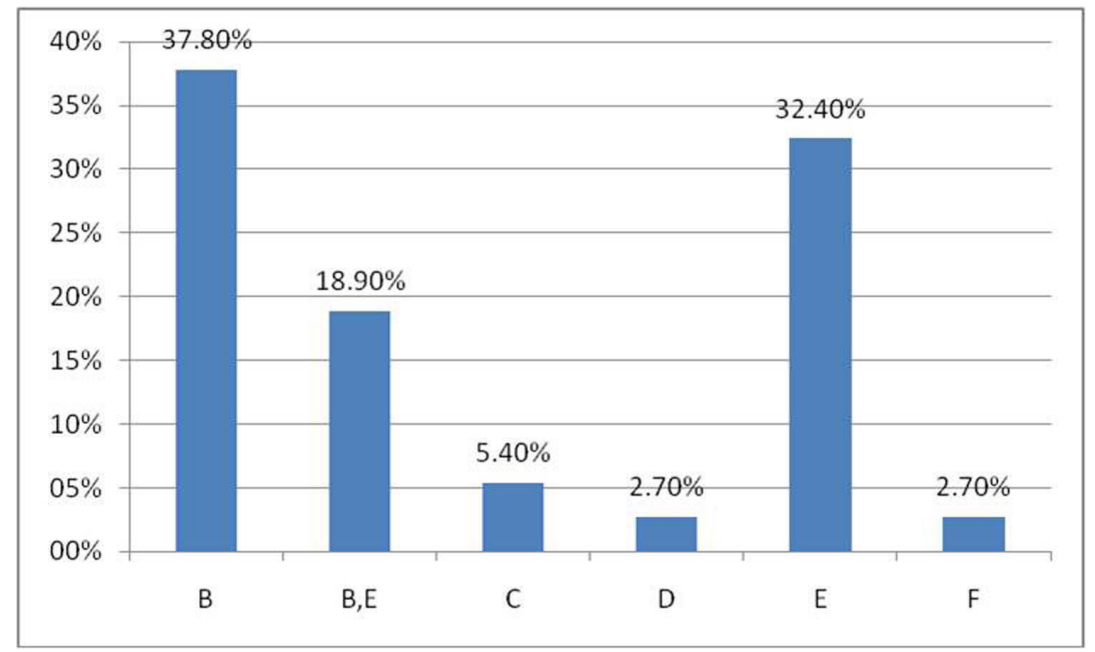

Fig. 2. Relative frequency of soft tissue calcifications according to the mandibular region. 

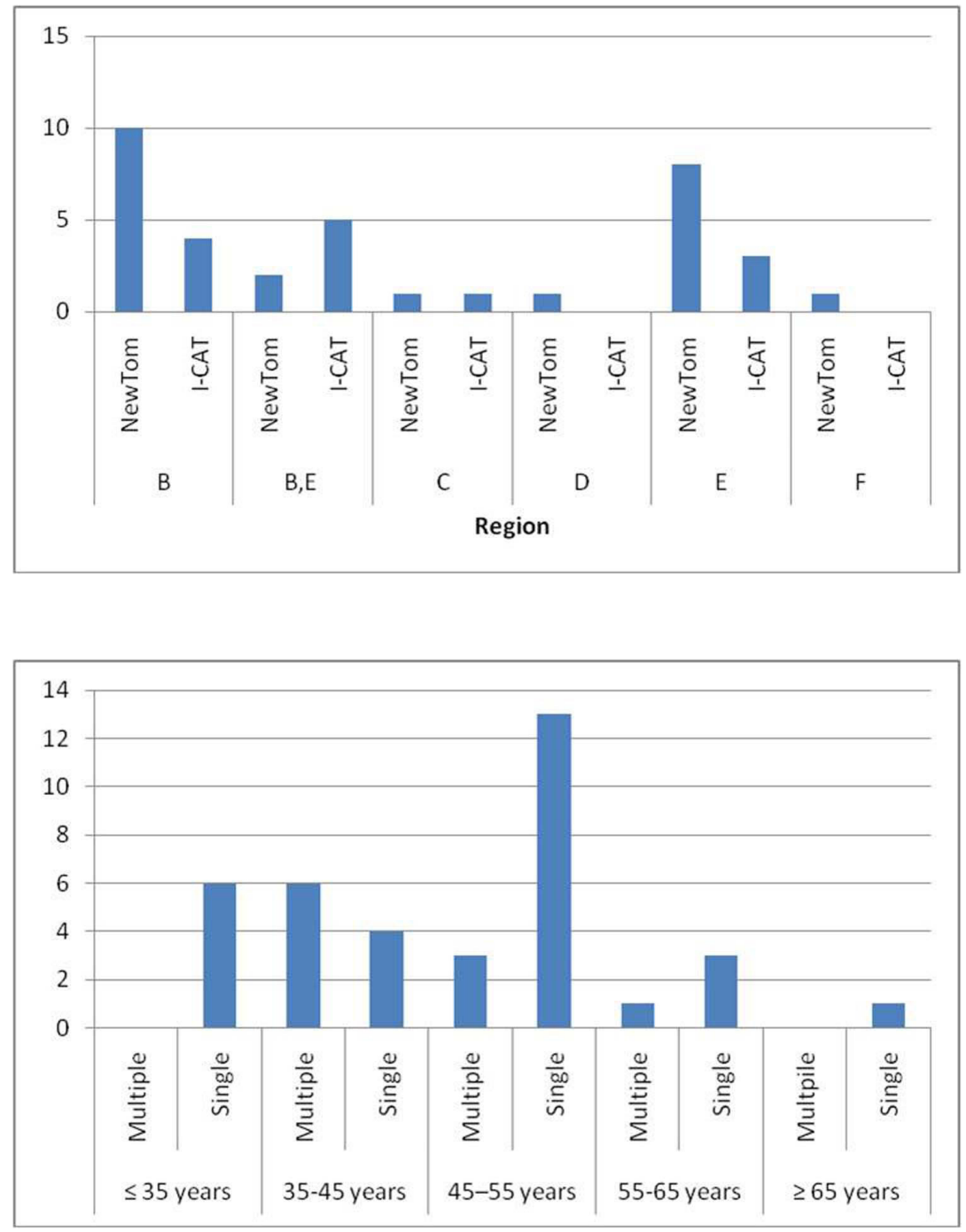

Fig. 3. Frequency of soft tissue calcifications according to the mandibular region and cone beam computed tomography system used.
Fig. 4. Frequency of single and multiple soft tissue calcifications according to the age group.

\section{Discussion}

Oral and maxillofacial radiologists are faced with a challenge when analyzing $\mathrm{CBCT}$ images: to interpret all of the structures depicted (which will vary according to the size of the field of view). This is mandatory in accordance with the guidelines of the American Academy of Oral and Maxillofacial Radiology (5), and soft tissue calcifications are among the relevant findings of a thorough analysis of CBCT images. In the present study, axial CBCT scans were assessed to detect soft tissue calcifications in the mandibular region, a procedure that is similar to that used to detect sialolithiasis on helical computed tomography (HCT) images $(6,7)$.

We did not adopt a gold standard for the evaluation of the accuracy of the CBCT systems in detecting soft tissue calcification, which is done when HCT images are compared. In addition, we analyzed scans from individuals who underwent $\mathrm{CBCT}$ using either the NewTom $3 \mathrm{G}^{\circledR}$ system or the Classic i-Cat ${ }^{\mathbb{B}}$ system, not both. Mischkowski et al. (8) and Suomalainen et al. (9) took CBCT and HCT scans of patients and of a cadaver mandible, respectively, to evaluate the diagnostic quality of the images and the precision of the linear measurements. Mischkowski et al. (8) found no significant differences between the two methods, whereas Suomalainen et al. (9) reported that CBCT generated less error. Pinsky et al. (10) reported that the images obtained by the Classic i-Cat ${ }^{\circledR}$ system were accurate in detecting bone defects. These results justify our decision of not using a gold standard for CBCT. Although there are consensus the accuracy of $\mathrm{CBCT}$ in detecting small calcified structures in soft tissues, the method has previously been reported as accurate.

The thickness of the slices used in the present study was $0.4 \mathrm{~mm}$. Calcifications such as sialoliths can go undetected if thicker slices are used (11). Drage and Brown (12), in the first report of the use of cone beam computed sialography, highlighted the importance of thin slices for the diagnosis of small sialoliths.

Cases of ossification of the stylohyoid ligament were excluded due to the difficulty in standardizing these cases, 
since there is no consensus regarding the definition of this phenomenon (13). The reported incidence of stylohyoid ligament ossification in the general population varies greatly. In addition, there is a large variability in the anatomy of the styloid process as seen in $3 \mathrm{D}$ reconstructions of $\mathrm{HCT}$ scans (14).

For the statistical analysis performed in the present study, the scans of patients with multiple calcifications were allocated to a separate group (7). However, when the cases of multiple calcifications in the same individual were evaluated, we added the cases of calcifications in more than one region, as well as those of more than one calcification in the same region. There were no significant difference of the prevalence of multiple calcifications between gender, age group, or CBCT systems (Fig. 4).

On CT scans, tonsilloliths and sialoliths often appear as large and hyperdense masses, which can be bilateral. However, Avrahami et al. (7) found small sialoliths in submandibular glands. Small calcifications in the tonsils can incidentally be found on CT scans, and $20 \%$ to $30 \%$ of all sialoliths are hypodense $(3,6,15-17)$. In the present study, only small calcifications were found; in the absence of records of the main complaint or the reason why the CT scan was requested, the presence of symptoms was not considered. In addition, the two CBCT systems evaluated in the present study might not have detected calcifications that were even smaller.

The greatest difficulty in the present study was the absence of soft tissue landmarks for the exact location of the calcifications. Moreover, CBCT images do not allow specialists to determine whether the calcification is inside a soft tissue lesion, such as a malignant neoplasm, which is one of the differential diagnoses (16). Furthermore, the lowcontrast resolution of CBCT images is not sufficient to allow the differentiation among soft tissue structures (8).

Despite the absence of soft tissue landmarks, we can assume that the calcifications that were closer to the midline, adjacent to the oropharynx, were located in the space that represented the pharyngeal mucosa (which has lymphatic tissue) and, therefore, they were tonsilloliths (1820). The calcifications that were close to the bone surface in the posterior region of the mandible were probably submandibular gland sialoliths, whereas those that were close to the bone surface in the anterior region of the mandible were probably sublingual gland sialoliths. Nevertheless, since the submandibular space also harbors submandibular and sublingual lymph nodes, tonsilloliths should be included in the differential diagnosis. The calcifications in the external part of the mandible were probably osteoma cutis.

In the present study, the prevalence of soft tissue calcifications was approximately $15 \%$ (Table 1 ). Shigehara et al. ${ }^{1}$ found that the incidence of osteoma cutis was $28 \%$, which is a figure well above the incidence reported in the literature. The authors reported that this was due to a wrong choice of technique (1). The prevalence of soft tissue calcifications found in the present study was also much higher than the reported prevalence, which might be due to the fact that all calcifications were grouped or to the fact that the prevalence of soft tissue calcifications has been underestimated in the literature. We found no studies on the incidence of soft tissue calcifications, only case reports of soft tissue calcifications.

This study showed only two cases of calcifications in the buccal part of the mandible. In one of these cases, the calcification appeared to be multiple, which is highly suggestive of osteoma cutis. We found two cases of calcifications in region $\mathrm{C}$, which were highly suggestive of sublingual gland sialoliths. Regions B and E, which were posterior regions of the mandible, in the lingual aspect, were the most affected, and the calcifications observed might have been sialoliths or tosilloliths, depending on their location (Fig. 2 and 3).

The age range of the 246 patients was extremely wide. Most of the CBCT scans were from patients in the 4555 year-old age group (71 subjects), with predominance of females (Table 2). Arnheiter et al. (21) found a mean age of $45 \pm 21$ year-old in the charts of 329 patients who underwent $\mathrm{CBCT}$, with higher frequency in females. In that study, CBCT scans were more common among patients in the 60-69 year-old age group, particularly in the subjects of the 50-59 year-old group (21).

In the present study, the mean age of patients was 44.9 years, and there was no significant difference between gender for the prevalence of soft tissue calcification. Bodner (4) and Ledesma-Montes et al. (22) found that most of the patients with sialoliths were in their 40's or 50's years-old, and that sialoliths were more common among males.

Since we did not classify the calcifications (we only determined their location in the axial plane), these findings cannot be directly compared with those reporting the incidence of tonsilloliths, sialoliths, and osteoma cutis. Knowledge of the anatomy of the maxillofacial region can aid in determining the tissue of origin of a calcification seen on a CBCT scan (23). Nevertheless, because we had no access to the clinical charts or test results that might have confirmed the diagnoses, we limited our analysis to the identification of calcifications. The $15 \%$ prevalence of soft tissue calcifications found in the present study confirms the importance of carefully observing serial CBCT scans in order to take full advantage of the diagnostic potential of this imaging modality.

Although NewTom $3 \mathrm{G}^{\mathbb{R}}$ and Classic i-Cat ${ }^{\mathbb{R}}$ have different image detectors (charge couple device/image intensifier and flat panel, respectively), there was no significant difference between the two CBCT systems in terms of the diagnostic quality of the images (Table 1). Naitoh et al. (24) showed that the image intensifier system produces more artifacts than does the flat panel detector. Mischkowski et al. (8) compared images obtained by the gold standard HCT system with those obtained by an image intensifier system and reported no significant difference between both for the identification of important anatomical structures in the mandibular region. Scarfe et al. (25) reported that, although the image detector and scan type of the $\mathrm{i}-\mathrm{Cat}^{\circledR}$ system generated less noise, 
better spatial resolution, and better contrast resolution, the dose of radiation was higher than the others.

The two CBCT systems evaluated in the present study revealed a similar prevalence of soft tissue calcifications, confirming that CBCT can effectively aid in establishing a more accurate diagnosis, regardless of the specifications of the equipment. We found a high prevalence of soft tissue calcifications in this sample, which highlight the importance of carefully analyzing CBCT images to detect soft tissue calcifications in the mandibular region. Based on these findings, all regions, age groups and gender can be affected, which means that the specialists should perform a thorough analysis of CBCT scans of all patients.
One limitation of the present study is that we did not perform linear measurements of the calcifications. Moreover, the same patients had not undergone CBCT using the two systems. Thus, further studies are required to determine the real impact of the image detectors on the diagnosis of soft tissue calcifications.

In conclusion, the prevalence of soft tissue calcifications was approximately $15 \%$ in this sample. Soft tissue calcification was predominant at the posterior region of the mandible (18.9\%), with no association with gender or age. There was no significant difference between the two CBCT systems (NewTom $3 \mathrm{G}^{\circledR}$ and Classic i-Cat ${ }^{\circledR}$ ) for the diagnostic quality of the images. multiple miliary osteomas of cadaver skin. Oral Surg Oral Med Oral Pathol Oral Radiol Endod 1998;86:121-5.

2. Gokcea C, Sismanb Y, Sipahiogluc M. Styloid process elongation or Eagle's syndrome: is there any role for ectopic calcification? Eur J Dent 2008;2:224-8.

3. Ram S, Siar CH, Ismail SM, Prepageran N. Pseudo bilateral tonsilloliths: a case report and review of the literature. Oral Surg Oral Med Oral Pathol Radiol Endod 2004;98:1 10-4.

4. Bodner L. Giant salivary gland calculi: diagnostic imaging and surgical management. Oral Surg Oral Med Oral Pathol Oral Radiol Endod 2002;94:320-3.

5. Howerton Jr WB, Mora MA. Use of conebeam computed tomography in dentistry. Gen Dent 2007;55:54-7.

6. Carter L, Farman AG, Geist J, Scarfe WC, Angelopoulos C, Nair MK et al. American Academy of Oral and Maxillofacial Radiology executive opinion statement on performing and interpreting diagnostic cone beam computed tomography. Oral Surg Oral Med Oral Pathol Oral Radiolo Endod 2008; 106:561-562.

7. Avrahami E, Englender M, Chen E, Shabtay D, Katz R; Harell M. CT of submandibular gland sialolithiasis. Neuroradiology 1996;38:287-90.

8. Mischkowski RA, Sherer P, Ritter L, Neugebauer J, Keeve E, Zöller JE. Diagnostic quality of multiplanar reformations obtained with a newly developed cone beam device for maxillofacial imaging. Dentomaxillofacial Radiol 2008;37:1-9.

9. Suomalainen A, Vehmas T, Kortesniemi M, Robinson S, Peltola J. Accuracy of linera measurements using dental cone beam and conventional multislice computed tomography. Dentomaxillofacial Radiol 2008;37:10-7.

10. Pinsky HM, Dyda S, Pinsky RW, Misch KA, Sarment DP. Accuracy of three-dimensional mesasurements using cone-beam CT. Dentomaxillofacial Radiol 2006;35:410-6.

11. Mandel L; Hatzis $G$. The role of computerizes tomography in the diagnosis and therapy of parotid stones: a case report. J Am Dent Assoc 2000;131:479-82.

12. Drage NA, Brown JE. Cone beam computed sialography of sialoliths. Dentomaxillofac Radiol 2009;38:301-5.

13. Vougiouklakis T. Overview of the ossified stylohyoid ligament based in more than 1200 forensic autopsies. J Clin Forensic Med 2006;13:268-70.

14. Ramandan SU, Gokharman D, Tunçbilek I, Kacar M, Kooar P, Kosar U. Assessment of the stylohoid chain by 3D-CT. Surg Radiol Anat 2007;29:583-8.

15. Pérez FJ, Guayo GM, Tabar AO, Broto JP. A propósito de un caso: gran onsilolito en amígdala palatina. Acta Otorrinolaringol Esp 2002;53:207-10.

16. Sezer B, Tugsel Z, Bilgen C. An unusual tonsillolith. Oral Surg Oral Med Oral Pathol Oral Radiol Endod 2003;95:471-3.

17. Mosca RC, Cabral MV, Mantesso A. Bilateral tonsilloliths in a 77-year-old white man with edentulous jaws: a case report. Oral Radiol 2006;22:34-6.

18. Kurubayashi T, Nakamura S, Ogura I, Sasaki T. The sublingual e submandibular spaces. Oral Radiol 2003,19:130-6.

19. Kimura Y, Okano T. The pharyngeal mucosal, parapharyngeal, and retropharyngeal spaces. Oral Radiol 2003;19:106-8.

20. Okano T. Lesions originating in the head and neck spaces and their differentiation: an introduction. Oral Radiol 2003; 19:104-5. 
21. Arnheiter C, Scarfe WC, Farnam AG. Trends in maxillofacial cone-beam computed tomography usage. Oral Radiol 2006;22:80-5.

22. Ledesma-Montes C, Garcés-Ortiz M, Salcido-Garcia JF, Hernandéz-Flores F, HernandézGuerrero JC. Giant sialolith: case report and review of the literature. J Oral Maxillofac Surg 2007;65:128-30

23. Angelopoulos $\mathrm{C}$. Cone beam tomographic imaging anatomy of the maxillofacial region. Dent Clin North Am 2008;52:731-52.

24. Naitoh M, Hirukawa A, Katsumata A, Saburi K, Okumura S, Ariii E. Imaging artifact and exposure conditions in limited-volume cone-beam computed tomography: comparison between an image intensifier system and a flat panel detector. Oral Radiol 2006;22: 69-74.

25. Scarfe WC, Farman AG, Sukovic P. Clinical applications of cone-beam computed tomography in Dental practice. J Can Dent Assoc 2006;72:75-80. 